\title{
Monitoring Cell of Hydrogen Permeated through Steel at High Temperatures*
}

\author{
By Harushige TSUBAKINO,** Kazuyuki FUKUMOTO*** \\ and Koji YAMAKAWA $A^{* * * *}$
}

\begin{abstract}
Synopsis
A cell and some monitor techniques for the content of hydrogen permeated through a $2 \frac{1}{4} \mathrm{Cr}-1 \mathrm{Mo}$ steel at high temperatures have been developed by using an electrochemical method. The cell was made of high-purity alumina, platinum-coated $\mathrm{MgO}$ stabilized zirconia tube (reference electrode), platinum wire (counter electrode) and two alumina tubes (inlet and outlet for argon gas), which were fixed to the cell. Molten $\mathrm{NaOH}$ was used as an electrolyte. The hydrogen permeation current obtained at $673 K$ and $0.101 \mathrm{MPa}$ hydrogen gas was consistent. The limit of hydrogen detection by this monitoring cell was $0.08 \mathrm{ppm}$. Therefore, the present monitoring cell will be useful for predicting hydrogen attack of steels in operating chemical plants.
\end{abstract}

Key words: monitoring cell; hydrogen content; high temperature; electrochemical method; steel; hydrogen attack.

\section{Introduction}

Steels exposed to hydrogen gas at high temperatures and high pressures result in a marked deterioration in their mechanical properties. This phenomenon, well known as hydrogen attack, is caused primarily by the nucleation, growth and coalescence of methane bubbles along grain boundaries accompanied by concomitant internal decarburization. ${ }^{1,2)}$

There have been many reports ${ }^{3-6)}$ on the accidents and damages caused by hydrogen attack in petrorefining plants and ammonia production plants. However, there is no method for prediction or monitoring of hydrogen attack. Many coal liquefaction plants will be operated at much higher temperatures and pressures of hydrogen gas in future. Therefore, development and establishment of prediction or monitoring method of hydrogen attack is indispensable.

In previous papers, ${ }^{7,8)}$ an electrochemical permeation method, usable widely at ambient temperatures, was developed to measure the hydrogen content in steels in the elevated temperature range of practical interest for hydrogen attack. Introduction and detection of hydrogen were performed by use of molten sodium hydroxide. Hydrogen attack is related to the content of hydrogen in steels which entered from hightemperature and high-pressure hydrogen gas environment. ${ }^{9)}$

The present report presents a monitoring cell and some field applications of this electrochemical detection method.

\section{Monitoring Cell and Experimental Apparatus}

Schematic representation of the monitoring cell which is capable to measure the hydrogen content of steels in actual plants is shown in Fig. 1. A highpurity alumina $\left(\mathrm{Al}_{2} \mathrm{O}_{3}>99.5 \%, 3.43 \mathrm{MPa}\right.$ in the three-point flexure) was selected as the cell materials, because alumina is stable against molten sodium hydroxide (m.p. $=595 \mathrm{~K}$ ) used as the electrolyte and the cell should be fixed tightly to the steel specimen to ensure permeation of hydrogen. A platinum-coated $\mathrm{MgO}$ stabilized zirconia tube as the reference air electrode $\left(\mathrm{Air} / \mathrm{O}^{2-}\left(\mathrm{ZrO}_{2}\right)\right)$, a platinum wire as the counter electrode, and two alumina tubes as the inlet and outlet for argon gas were fixed to the cell with alumina cement. Two round grooves were cut on the bottom surface of the cell to keep two O-rings of gold wire ( $2 \mathrm{~mm}$ in diameter) for sealing the electrolyte. The inner diameter of cell was $6.7 \times 10^{-2} \mathrm{~m}$ and the monitoring area was $3.5 \times 10^{-3} \mathrm{~m}^{2}$.

The specimen used in the present study was a plate of $2 \frac{1}{4} \mathrm{Cr}-1 \mathrm{Mo}$ steel $\left(100 \times 100 \times 10 \times 10^{-9} \mathrm{~m}^{3}\right)$. The chemical composition of the specimen is shown in Table 1.

The specimen surface for detection of hydrogen

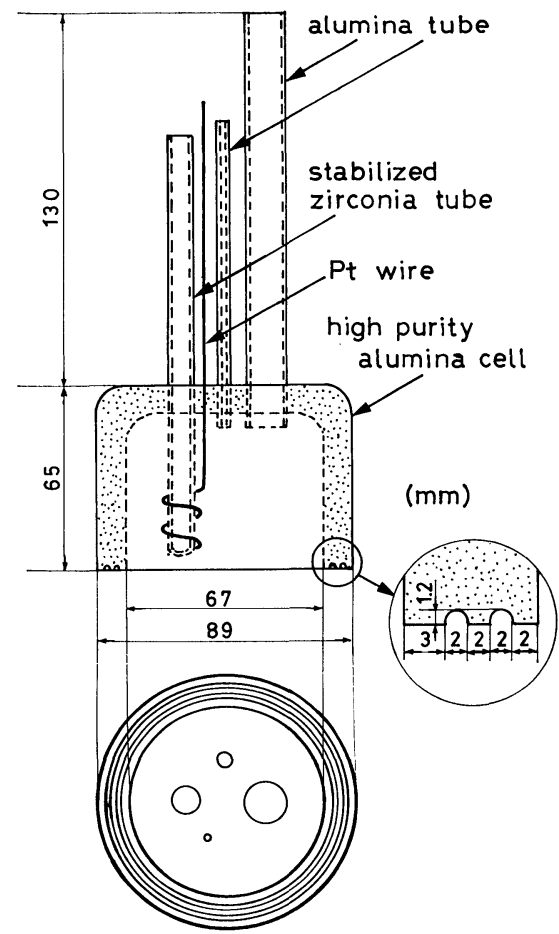

Fig. 1. Schematic representation of monitoring cell.

\footnotetext{
* $\quad$ Manuscript received on August 21, 1987; accepted in the final form on September 11, 1987. (C) 1988 ISIJ

** Formerly College of Engineering, University of Osaka Prefecture. Now at Himeji Institute of Technology, Shosha, Himeji 671-22.

*** Graduate School, University of Osaka Prefecture, Mozu-Umemachi, Sakai 591.

**** College of Engineering, University of Osaka Prefecture, Mozu-Umemachi, Sakai 591.
} 
Table 1. Chemical composition of $2 \frac{1}{4} \mathrm{Cr}-1 \mathrm{Mo}$ steel. (wt\%)

\begin{tabular}{ccccccc}
\hline $\mathrm{G}$ & $\mathrm{Si}$ & $\mathrm{Mn}$ & $\mathrm{P}$ & $\mathrm{S}$ & $\mathrm{Gr}$ & Mo \\
\hline 0.12 & 0.05 & 0.51 & 0.006 & 0.012 & 2.22 & 1.02 \\
\hline
\end{tabular}

(denoted B in Fig. 2) was mechanically polished with emery papers up to \#800. After cleaning with acetone, the surface was electroplated with gold, about $0.5 \mu \mathrm{m}$ in thickness, on a $0.05 \mu \mathrm{m}$ thick nickel flushplating to prevent anodic dissolution of the specimen.

At the entry side of hydrogen (denoted A in Fig. 2), the chamber to accomodate hydrogen gas was welded in advance to the specimen plate. High purity hydrogen gas $(99.999 \%$ ) was flowed with a rate of $40 \sim$ $60 \mathrm{ml} / \mathrm{min}$ to keep the hydrogen pressure at 0.101 $\mathrm{MPa}(1 \mathrm{~atm})$.

The cell was set to the specimen tightly with a fixing plate, 4 bolts, and 8 nuts made of $2 \frac{1}{4} \mathrm{Cr}-1 \mathrm{Mo}$ steel. After setting the cell, solid sodium hydroxide was dropped into the cell through the alumina tube fixed to the cell. During heating up the apparatus and measuring the permeation current, argon gas was supplied through the alumina tubes with a flow rate of $60 \mathrm{ml} / \mathrm{min}$. The temperature was kept at 673 $\pm 2 \mathrm{~K}$.

\section{Experimental Results and Discussion}

Ghange of the permeation current with time was measured at a constant anodic potential, $-0.6 \mathrm{~V} v s$. Air $/ \mathrm{O}^{2-}\left(\mathrm{ZrO}_{2}\right)$, which was in the range enough to ionize hydrogen upon permeation through steel. $\left.{ }^{8}\right)$ The results are shown in Fig. 3. The time was taken as zero, in this figure, when the temperature reached to $673 \mathrm{~K}$. The hydrogen permeation current was nearly constant at about $1 \mathrm{~mA}$. For the first day, the permeation current could not be detected, because sodium hydroxide should drop into cell slowly and it took about one day to fill about $4 / 5$ of the cell depth with sodium hydroxide.

The permeation current density in the steady state, $J_{\infty}\left(\mathrm{A} / \mathrm{m}^{2}\right)$, is related to the hydrogen content $C_{\mathrm{o}}$ $(\mathrm{ppm})^{8)}$ :

$$
C_{\mathrm{o}}=10^{6} \frac{J_{\infty} \cdot L}{F \cdot D \cdot d}
$$

where, $D:$ the diffusion coefficient of hydrogen in the specimen $\left(\mathrm{m}^{2} / \mathrm{s}\right)$

$d:$ the density of steel $\left(\sim 7.86 \times 10^{6} \mathrm{~g} / \mathrm{m}^{3}\right)$

$F:$ the Farady constant

$L:$ the specimen thickness (m).

The $D$ values obtained from the same electrochemical method as reported previously ${ }^{8)}$ are shown in Fig. 4. The obtained $D$ values were in scatter. However, $D$ at $673 \mathrm{~K}$ was fairly in good agreement with the other reports that were obtained from the usual gaseous method..$^{10,11)}$

The concentration of dissolved hydrogen in steels, $C_{0}$, is proportional to the square root of the hydrogen pressure, $P$, and is known as Sieverts' law, that is,

$$
C_{\mathrm{o}}=a \sqrt{P} \exp (-\Delta H / R T)
$$

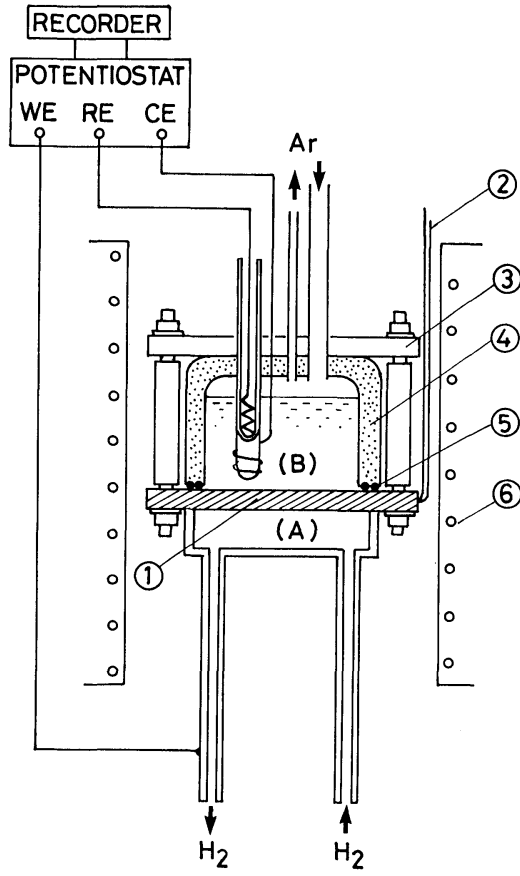

(A): Entry side of hydrogen $(99.999 \%$ hydrogen gas)

(B): Detection side of hydrogen (molten sodium hydroxide)

WE: Working electrode (specimen)

RE: Reference electrode (Air/O $\mathrm{O}^{2-}\left(\mathrm{ZrO}_{2}\right)$ )

GE: Counter electrode (platinum wire)

(1): Specimen $\left(2 \frac{1}{4} \mathrm{Cr}-1\right.$ Mo steel)

(2): Thermocouple

(3): Cell fixing plate

(4): Monitoring cell

(5): Gold O-ring

(6): Furnace

Fig. 2. Schematic representation of apparatus.

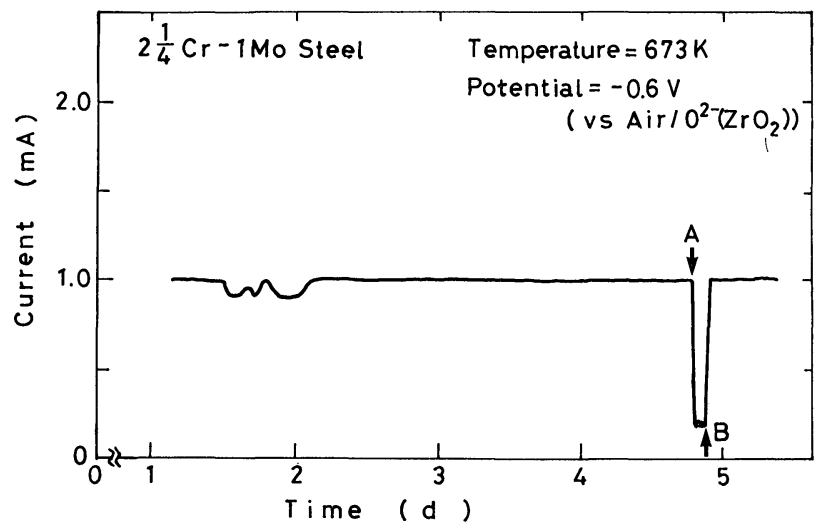

The hydrogen pressure: $0.101 \mathrm{MPa}$

A: Change of hydrogen gas to argon gas

B: Change of argon gas to hydrogen gas

Fig. 3. Change of hydrogen permeation current with time.

where, $a:$ a constant

$\Delta H:$ the enthalpy change associated with dissolution of hydrogen in steel

$R$ : the gas constant

$T$ : the test temperature.

The published data ${ }^{11-14)}$ for $a$ and $\Delta H$ in steels, and 


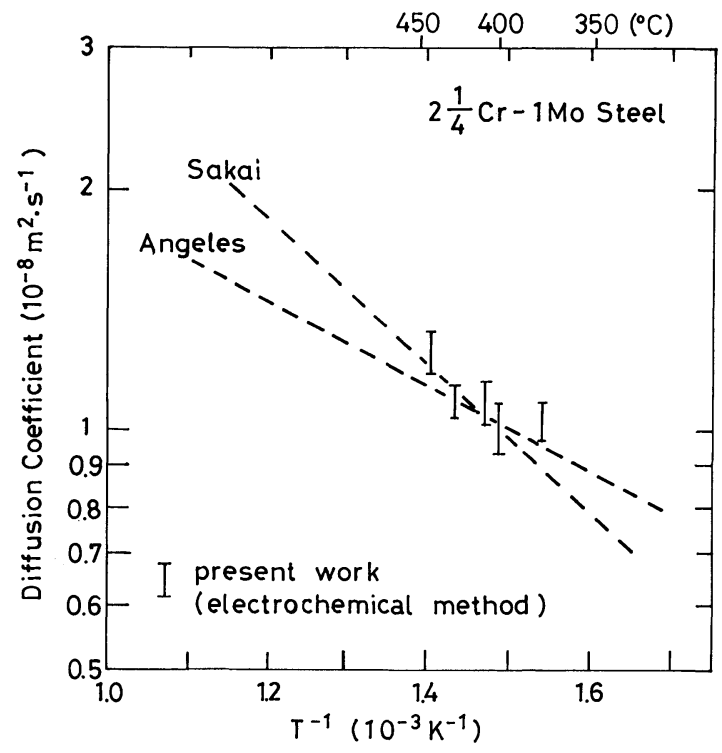

Fig. 4. Arrehenius plots of diffusion coefficient of hydrogen in $2 \frac{1}{4} \mathrm{Cr}-1 \mathrm{Mo}$ steel.

the calculated $C_{0}$ values at $673 \mathrm{~K}$ and $0.101 \mathrm{MPa}$ hydrogen pressure from these data are summarized in Table 2.

The $C_{\mathrm{o}}$ value evaluated from the permeation current density is included in Table 2. This evaluation needed the residual current density of this monitoring cell. The hydrogen gas was pumped out and changed to argon gas at the time marked $\mathrm{A}$ in Fig. 3. The permeation current decreased down to $0.2 \mathrm{~mA}$ and remained at the level as the residual current for several hours. At the time B, the argon gas was pumped out and changed to the hydrogen. The permeation current recovered to the previous level of $1 \mathrm{~mA}$. This results indicate that the monitoring method has high reliability. The value of $C_{0}$ was evaluated from the difference between the permeation current and residual current densities. Table 2 shows that the $C_{\mathrm{o}}$ value obtained in the present study is reasonable, compared with those obtained from the published data. ${ }^{11-14)}$

The critical hydrogen content for hydrogen attack is about $0.6 \mathrm{ppm}$ for a plain carbon steel and 2.4 $4.3 \mathrm{ppm}$ for a Cr-Mo steel.9) The detectability of the new monitoring apparatus is $0.08 \mathrm{ppm}$ from the residual current density and is satisfactory for monitoring of hydrogen attack of steels.

Therefore, the present cell will be useful for on-line monitoring of the content of hydrogen which enters from environment in operating chemical plants.

\section{Conclusions}

A cell and the related techniques to measure the hydrogen content in a $2 \frac{1}{4} \mathrm{Gr}-1 \mathrm{Mo}$ steel have been de-
Table 2. Parameters of hydrogen content and calculated hydrogen content, $C_{0}$, at $673 \mathrm{~K}$ and at $0.101 \mathrm{MPa}$ of hydrogen pressure.

\begin{tabular}{lcccc}
\hline \multicolumn{1}{c}{ Steel } & $\begin{array}{c}a \\
\left(\mathrm{ppm} \cdot \mathrm{Pa}^{-1 / 2}\right)\end{array}$ & $\begin{array}{c}\Delta H \\
\left(\mathrm{~kJ} \cdot \mathrm{mol}^{-1}\right)\end{array}$ & $\begin{array}{c}C_{\mathrm{o}} \\
(\mathrm{ppm})\end{array}$ & Ref. \\
\hline $0.47 \mathrm{Si}-0.19 \mathrm{Mn}$ & 0.135 & 27.3 & 0.33 & $12)$ \\
$0.13 \mathrm{Si}-0.70 \mathrm{Mn}$ & 0.154 & 28.5 & 0.30 & $13)$ \\
$2 \frac{1}{4} \mathrm{Cr}-1 \mathrm{Mo}$ & 0.0747 & 27.1 & 0.19 & $11)$ \\
$\alpha$-iron & 0.133 & 27.2 & 0.33 & $14)$ \\
\hline This study & & & 0.30 & \\
\hline
\end{tabular}

veloped for field application. The cell was made of high purity alumina and was connected with a stabilized zirconia tube used as the reference electrode (Air $\left./ \mathrm{O}^{2-}\left(\mathrm{ZrO}_{2}\right)\right)$, a platinum wire as the counter electrode and two alumina tubes as the inlet and outlet for argon gas.

The hydrogen permeation current obtained at $673 \mathrm{~K}$ was consistent. The detectability of hydrogen with the new cell was high enough to monitor hydrogen attack of steels.

Therefore, the present monitoring cell will be useful for predicting the hydrogen attack of steels in operating chemical plants.

\section{Acknowledgement}

A part of this study was supported by Grant-in-Aid for Scientific Research from the Ministry of Education, Science and Gulture, Japan.

\section{REFERENCES}

1) H. Tsubakino and K. Yamakawa: Tetsu-to-Hagané, 71 (1985), 1070.

2) P. G. Shewmon: Mater. Sci. Technol., 1 (1985), 2.

3) K. Ishizuka and R. Chiba: Tetsu-to-Hagané, 56 (1970), 93.

4) K. Yamakawa: J. Soc. Mater. Sci. Jpn., 25 (1976), 1110.

5) J. Watanabe: Tetsu-to-Hagané, 64 (1978), 1020.

6) API Publ. 941, 3rd ed., API, Washington D.C., (May, 1983).

7) H. Tsubakino, A. Ando, K. Yamakawa: Scr. Metall., 18 (1984), 1121.

8) H. Tsubakino, A. Ando, T. Masuda and K. Yamakawa: Trans. Iron Steel Inst. Jpn., 26 (1986), 775.

9) H. Tsubakino and K. Yamakawa: Corros. Eng. (Jpn), 33 (1884), 159.

10) O. F. Angels, R. I. Stueber and G. H. Geiger: Corrosion, 32 (1976), 179.

11) T. Sakai, K. Asami, M. Katsumata, H. Takada and O. Tanaka: Gurrent Solutions to Hydrogen Problems in Steels, ed. by G. G. Interrante and G. M. Pressouyre, ASM, Ohio, (1982), 340.

12) W. Geller and T-H. Sun: Arch. Eisenhüttenwes., 21 (1950), 423.

13) M. H. Armbruster: J. Amer. Chem. Soc., 65 (1943), 1043.

14) O. D. Gonzalez: Trans. Metall. Soc. AIME, 245 (1969), 607. 